\title{
Challenges of Environmental Management Systems Implementation in Ghanaian Firms
}

\author{
Samuel Famiyeh ${ }^{1}$, Saint Kuttu ${ }^{1} \&$ Ebenezer Bugri Anarfo ${ }^{1}$ \\ ${ }^{1}$ GIMPA Business School, Ghana Institute of Management and Public Administration, Accra, Ghana \\ Correspondence: Samuel Famiyeh, GIMPA Business School, Ghana Institute of Management and Public \\ Administration, Accra, Ghana P.O. Box AH 50, Achimota, Accra, Ghana. Tel: 233-21-401-0681. E-mail: \\ sfamiyeh@gimpa.edu.gh
}

\author{
Received: November 1, 2013 Accepted: January 14, 2014 Online Published: January 21, 2014 \\ doi:10.5539/jsd.v7n1p105 \\ URL: http://dx.doi.org/10.5539/jsd.v7n1p105
}

\begin{abstract}
Environmental management can be described as a methodology by which organizations acting in a structured manner assess their operations to ensure that they are functioning in an environmentally legitimate way. This study seeks to investigate barriers of environmental management systems implementation in Ghana. In all, fifty three environmental representatives were surveyed and the results show that the top most important factors hindering the implementation of environmental management implementation were: implementation cost and "too much paper work", the cost of certification, the quality of consultants, the time involved and the exposure of the organizations to regulatory bodies. Lack of human resources, the understanding of the system, the effect of environmental management system on the existing structure and its intended benefits do not seem to be barriers in Ghana.
\end{abstract}

Keywords: Ghana, systems, EMS, driving forces, environmental management

\section{Introduction}

Concerns about effective management of the natural environment have intensified over the last decade (Gray, 2010). From supranational agencies to political and corporate leaders, the preservation of the physical environment has increasingly occupied centre-stage and continues to engender considerable debates about how to tackle this seemingly gargantuan task (Porter \& van der Linde, 1995; Everett \&Neu, 2000; Rahaman, Lawrence, \& Roper, 2004). The consequences of not managing the organizational environment properly may result in severe pollution and other related problems, which may kill thousands of people and damage the physical environment (Ritchie \& Hayes, 1998).

Hawken (1993) argues that an enduring society must be based on a system of commerce and production that is sustainable and restorative. Sustainable development is an approach that uses the earth's resources in such a way that future generations' needs are not compromised. In other words, sustainable development seeks a balance between economic growth and environmental protection. This implies that countries and businesses need to integrate economic, biological, and human systems to create a sustainable system of commerce (Beate \& Griessler, 2005) and that governments need to incorporate flexibility that rewards proactive environmental management. To support the transition to systematic, strategic management of environmental responsibilities, Adegbite, Amiolemen, Ologeh, and Oyefuga (2012) indicate that many companies have begun to adopt environmental management systems (EMS) to help them manage environmental issues more effectively. Whitelaw (1997) describes Environmental management as a methodology by which organisations acting in a structured manner assess their operations to ensure that they are functioning in an environmentally legitimate way. An environmental management system is a management system that aims to encourage an organization to control its environmental impacts and reduce such impacts continuously.

ISO 14000 series of standards or the International Standard for Environment which was released in September 1996, was developed to provide a common ground for evaluating and benchmarking an organisation's EMS (Standards Australia, 1996; Hale, 1997; Erickson \& King, 1999; Lutz, 2000). The ISO 14001 standard involves implementation and continuous improvement of five key elements: environmental policy; planning; implementation and operation; checking and corrective action; and management review (Standards Australia, 1996; Krut \& Gleckman, 1998; Erickson \& King, 1999; Nattrass \& Altmore, 1999). Adoption of ISO 14001 has 
also been shown to provide both tangible and intangible benefits to companies, such as: cost reductions and savings; improved communication; reduction in fines; improved corporate image; and improvement in operational processes, to name a few (Nee \& Wahid, 2010; Ayarkwa Joshua, 2010; West \& Manta, 1996; Maxwell, Rothenberg, Briscoe, \& Marcus, 1997; Chandrashekar, Dougless, \& Avery, 1999; Nattrass \& Altmore, 1999; Zingale \& Himes, 1999; Darnall, Gallagher, Andrews, \& Amaral, 2000; Hanna, Newman, \& Johnson, 2000; Lee-Mortimer, 2000; Schaarsmith, 2000; Daily \& Huang, 2001).

Although there has been considerable evidence on the benefits such as legal compliance, financial benefits through savings in consumption of utilities (Palmer \& France, 1998, Boiral \& Sala, 1998), financial and overall performance, (Melnyk, Sroufe, \& Calantone, 2003) there is the need to understand that every system developed to control the environment may confront management with new challenges that cannot be overlooked (Berenz, 1997; Butterbrodt, 1995; Figura, 1996; Forkert, Hofmann von Kap-herr, \& Pfeifer, 1997; Helling \& Herrmann, 1997; Sissell, 1996; Stielow, 1997). This brings to bare the importance to consider the challenges confronting organizations especially those in Sub-Saharan Africa as far as the implementation of an environmental management systems is concerned. Understanding these challenges and addressing them will assist increasing implementation that will result in achieving the "triple bottom line" in sustainable development (Hawken, 1993). The purpose of this paper is to examine the challenges and constraints facing organizations in Ghana in their quest to achieve environmental excellence through the implementation of environmental management systems.

The rest of this paper is structured as follows. First, we present a summary of relevant literature pertaining to the challenges as far as the implementation of environmental management systems is concerned. Second, the proposed theoretical framework or the methodology is outlined, explaining all the variables, and the method of measurement. Third, sample characteristics and the analysis are put forward. Then the main findings, conclusions, and implications are discussed. Finally, the study's limitations and potential future research directions are presented.

\section{Literature Review}

Any step involving the achievement of good environmental quality, inevitably involves some costs. This applies to the implementation of ISO 14001 environmental management systems and for that matter every environmental management system. A major source of irritation for SMEs, surfacing in a number of studies, is the cost of certification/validation (Goodchild, 1998; Bansal \& Hunter, 2003; Hillary, 1998; Hillary, 1997a; KPMG Environmental Consulting, 1997; Ayirebi-Dansoh, Ayarkwa, \& Amoah, 2010). Organisations are also aggrieved by the cost and quality of consultants advising them (KPMG Environmental Consulting., 1997), (NALAD, 1997). There are two costs, the cost of implementation and the cost of maintenance of the EMS. The implementation costs include costs incurred from activities a company undertakes to comply with the environmental management system which involves planning, identifying impacts and develop management plans, training and awareness, communication, documentation and document control, environmental functional reviews, miscellaneous, and the registration process. The maintenance costs however comprises of the costs incurred in monitoring the EMS, records related to the EMS, auditing and the cost involved in reviewing the EMS to enable continual improvement. Human rather than financial resources are the major barriers impeding EMS implementation, (Poole, Coombs, \& Van Gool, 1999; Goodchild, 1998).

Apart from the costs involved, the institutional arrangements and polices can in some ways affects the number of organizations implementing an environmental management system. In the global market place companies considers institutions and public policies to be critical elements of the business environment. The institutional environment, which creates the rules of the game among economic agents, influences an agent's ability to efficiently contract with other agents (Williamson, 1996). This in most cases put constraints on industrial organizations, the market in which they operate, and the way firms responds to this institutions. In the environmental arena, the institutional environment is an essential influencing factor for firms because it creates not only the rules of the game, but also the market for environmental products and services (Reinhardt \& Vietor, 1996). Uncertainty in the institutional environment, such as the behavior of environmental regulatory agencies could prevent firms from seeking certification after implementation. For example, regulatory violations by an ISO applicant firm might be revealed or disclosed during its environmental certification process, and if such violations are used by regulatory agencies or other third parties against the applicant firm, then such legal proceedings would result in additional cost of certification to the applicant firm.

Firms considering ISO certification struggle with the potential for discovery of regulatory violations that the firm has not yet identified or resolved (Naomi Roht-Arriaza, 1995). The process of ISO 14001 certification, may inadvertently lead to the discovery of non-compliance with applicable environmental regulations. Companies 
forcing to be in compliance with environmental laws and regulations always think of the identification of violations during the implementation phase, self or third-party audits can lead to real liabilities to the firm.

Another potential risk of liability comes from the fact that tracking the effectiveness of the system, requires organizations to document the details of environmental aspects of their operations that are not related to compliance with any regulatory scheme. Audits conducted under ISO 14001 check these documents and may point out weaknesses in the firm's handling of environmental matters, such as records of system failures and minor spills. These findings, while they may not be governed by any regulations, might still be used as incriminating evidence in future legal proceedings. In effect, an organisation adopting an EMS with a written policy specifying targets and objectives on environmental matters may also be defining a standard under which it may be held accountable (Mostek, 1998).

\section{Method}

A structure questionnaire was used to solicit information for this study. The key respondents for the study were environmental, health, safety, operations and administrative officers and managers who are major environmental decision makers when it comes to environmental management issues relating within their organizations. Highly experienced group of experts in administration, operations, marketing, occupational health, safety and environmental management who were on a special programme in occupational safety, health and environmental management in one of the top business schools in Ghana, were interesting and appropriate population to study because of their unique characteristics. The same procedure has been used by Chan (2001) in determining Chinese consumers' green purchasing behavior.

Contact persons (i.e. lecturers/professors or administrators) were used in distributing the questionnaire among these respondents. The questionnaires were administered and completed in the classroom. Respondents responded voluntarily and were not compensated for their participation. A total of 55 questionnaires were distributed but only 53 were usable. Confidentiality of responses was emphasized in the cover letter with the title 'confidential survey' and in the text. Before embarking on the data collection, two environmental experts were first invited to assess the instrument. Issues of importance in the questionnaire were the existence of an environmental management system and the challenges organizations face during the implementation of environmental management systems. The factors identified as challenges or barriers for the successful implementation of EMS in this study included; implementation cost, quality of consultants, too difficult to understand, seems not too beneficial, lack of human resources, effect on the existing organizational structures, cost of certification a bit too high, too much paper work involved in the process, time involved is a bit too high and sometimes exposes the organization environmental weakness to regulatory bodies to take advantage of. The conceptual model used was derived from Hillary (1998); Poole, Coombs and Van Gool (1999); Roht-Arriaza (1995); Bansal and Hunter (2003) and Mostek (1998). For the purposes of this study, we wanted to gain a 'deep understanding' of the key challenges faced by organizations in Ghana during the implementation of Environmental Management System (EMS) or Environmental Management Plan (EMP as referred to by the Ghana Environmental Agency (EPA)) based on a survey.

\section{Results}

\subsection{Background Information of Respondent and Organizations Surveyed}

The study surveyed fifty three (53) officers/managers with number of years of working ranging between five to sixteen or more. Their respective organizations have also been operating for five to sixteen or more years. Table 1 presents how long respondents' organizations have been operating.

Table 1 . How many years has your organization been operating?

\begin{tabular}{ccccc}
\hline \multicolumn{5}{c}{ Frequency } \\
\hline Valid 5 years or less & 10 & 18.9 & 18.9 & 18.9 \\
6-10 yrs & 6 & 11.3 & 11.3 & 30.2 \\
$11-15$ yrs & 9 & 17.0 & 17.0 & 47.2 \\
16 yrs or above & 28 & 52.8 & 52.8 & 100.0 \\
Total & 53 & 100.0 & 100.0 & \\
\hline
\end{tabular}


From Table 1, it can be seen that out of a sample of fifty three (53), ten (10) respondents said their organization have been operating for less than 5 years, 6 respondents said their organization have been operating 6 to 10 years, 9 respondents said 11 to 15 years now and 28 of them said their organization have been operating over sixteen (16) years representing $18.9,11.3,17.0$ and $52.8 \%$ respectively.

\subsection{Department of Respondents}

During this phase of the survey, respondents were asked to indicate which departments they belong to as far as the operations of their organizations are concerned. The departments of respondents have been presented in Table 2.

Table 2. Respondents departments

\begin{tabular}{ccccc}
\hline \multicolumn{5}{c}{ Frequency } \\
\hline Valid Administration & 2 & 3.8 & 3.8 & 3.8 \\
Operations & 15 & 28.3 & 28.3 & 32.1 \\
HSE & 21 & 39.6 & 39.6 & 71.7 \\
Marketing & 3 & 5.7 & 5.7 & 77.4 \\
Other & 12 & 22.6 & 22.6 & 100.0 \\
Total & 53 & 100.0 & 100.0 & \\
\hline
\end{tabular}

As shown in Table 2, respondents participating in the survey belongs to four key departments; viz. Administration, operations, marketing, health, safety and environment. In all there were 2, 15, 21, and 3 respondents working with administration, operations, HSE and Marketing representing 3.8, 28.8, 39.6 and 5.7 percent respectively. Twelve of the respondents representing 22.6 percent indicated that they were working in other departments other the above.

\subsection{Industrial Sector of Respondents}

Here respondents were asked to indicate the industrial sectors of their respective organizations. The various sectors which participated in the survey have been presented in Table 3.

Table 3. Industrial Sector of Respondents

\begin{tabular}{|c|c|c|c|c|c|}
\hline \multirow{2}{*}{$\overline{\text { Valid }}$} & & \multicolumn{4}{|c|}{ Frequency Percent Valid Percent Cumulative Percent } \\
\hline & mining & 15 & 28.3 & 28.3 & 28.3 \\
\hline & energy & 3 & 5.7 & 5.7 & 34.0 \\
\hline & chemical and paints & 3 & 5.7 & 5.7 & 39.6 \\
\hline & pharmaceuticals & 1 & 1.9 & 1.9 & 41.5 \\
\hline & food & 2 & 3.8 & 3.8 & 45.3 \\
\hline & financial institution & 2 & 3.8 & 3.8 & 49.1 \\
\hline & education & 4 & 7.5 & 7.5 & 56.6 \\
\hline & construction & 3 & 5.7 & 5.7 & 62.3 \\
\hline & Health & 5 & 9.4 & 9.4 & 71.7 \\
\hline & agriculture & 1 & 1.9 & 1.9 & 73.6 \\
\hline & other & 14 & 26.4 & 26.4 & 100.0 \\
\hline & Total & 53 & 100.0 & 100.0 & \\
\hline
\end{tabular}

As shown in Table 3, the key sectors which participated in the survey were: Mining, energy, chemical/paints, pharmaceuticals, food, financial institution, education, construction, health and agriculture. The most participated was the mining sector. 


\subsection{Respondents' Awareness of Environmental Management System (EMS)}

This section of the survey aimed at soliciting respondents' familiarity and awareness of environmental management system as a tool in managing pollution. Respondents were asked whether they were familiar with Environmental Management Systems (EMS). Table 4 presents the details of the analysis of the respondents' awareness of environmental management system.

Table 4. Respondents Awareness of Environmental Management Systems (EMS)

\begin{tabular}{cccccc}
\hline \multicolumn{5}{c}{ Frequency } & Percent \\
\hline Valid & Yes & 49 & 92.5 & 96.1 & 96.1 \\
& No & 2 & 3.8 & 3.9 & 100.0 \\
Total & 51 & 96.2 & 100.0 & \\
Missing System & 2 & 3.8 & & \\
Total & 53 & 100.0 & & \\
\hline
\end{tabular}

As shown in Table 4, forty nine (49) of the respondents representing $92.1 \%$ of the total indicated they are familiar with Environmental Management Systems and only two (2) of them 3.8\% indicated they were not familiar with Environmental Management Systems. Two (2) of the respondents did not answer that question and hence was indicated as missing also representing $3.8 \%$ of the total sample.

\subsection{Challenges of Environmental Management System Implementation}

\subsubsection{Descriptive Analysis}

This study examines factors that serve as barriers for the implementation of environmental management system (EMS) in organizations. The factors identified as challenges or barriers for the successful implementation of EMS in this study included; implementation cost, quality of consultants, too difficult to understand, seems not too beneficial, lack of human resources, effect on the existing organizational structures, cost of certification a bit too high, too much paper work involved in the process, time involved is a bit too high and sometimes exposes the organization environmental weakness to regulatory bodies to take advantage of. Respondents were asked to rate these factors on a five-point Likert scale as to whether a particular factor is indeed a barrier or a challenge for the successful implementation of environmental management systems in their organizations. The five-point scale include: $1=$ strongly disagree, $2=$ disagree, $3=$ neutral, $4=$ agree, $5=$ strongly agree.

The mean values and standard deviations of these environmental management system implementation challenges or barriers are presented in Table 5. From the table, implementation cost and "too much paper work" seems to be the two most important factors that hinders the implementation of environmental management systems in Ghana with mean values of 4.38 and 4.08 with standard deviations of 0.89 and 0.99 above the mean respectively. The next four most important factors hindering the implementation of environmental management system implementation were; the cost of certification, the quality of consultants, the time involved and the exposure of the organizations to regulatory bodies scoring mean values of 3.97, 3.93, 3.82 and 3.70 respectively.

Lack of human resources, the understanding of the system, the effect of environmental management system on the existing structure and its intended benefits scored mean values of 3.20, 3.20, 2.72 and 2.42 respectively indicating these factors do not hinder the implementation of environmental management systems in Ghana. 
Table 5. Descriptive statistics

\begin{tabular}{lccccc}
\hline Variable & Obs & Mean & StdDev & Min & Max \\
\hline IMPLEMENT & 47 & 4.382979 & .8981428 & 1 & 5 \\
QUALITY & 46 & 3.934783 & .9522412 & 1 & 5 \\
TOODIFF & 43 & 3.209302 & 1.124577 & 1 & 5 \\
SEEMSNOTT & 47 & 2.425532 & 1.156168 & 1 & 5 \\
LACKOFHUM & 41 & 3.243902 & 1.019325 & 1 & 5 \\
EFFECTING & 47 & 2.723404 & 1.174033 & 1 & 5 \\
COSTOFCERT & 47 & 3.978723 & .9438442 & 1 & 5 \\
TOOMUCHP & 47 & 4.085106 & .9962929 & 1 & 5 \\
TIMEINVOLV & 47 & 3.829787 & .9399156 & 1 & 5 \\
SOMETIMESE & 48 & 3.708333 & 1.12908 & 1 & 5 \\
\hline
\end{tabular}

IMPLEMENT $=$ implementation cost, QUALITY=quality of consultants, TOODIFF $=$ too difficult to understand, SEEMSNOTT=seems not too beneficial LACKOFHUM=lack of human resources, EFFECTING=affecting the existing organizational structures, COSTOFCERT $=$ cost of certification a bit too high, TOOMUCHP $=$ too much paper work involved in the process, TIMEINVOLV=time involved is a bit too high SOMETIMESE $=$ sometimes exposes the organization to environmental weakness to regulatory bodies to take advantage of.

\subsubsection{Correlation Analysis}

Due to the problem of multicollinearity among variables a correlation matrix of the variables used in the study are presented in table 6 . From Table 6, there is no much multicollinearity problem between the variables used in the study except for some few variables. Too much paper work correlates with cost of certification with a correlation co-efficient of 0.7116 and also quality of consultant's correlates with implementation cost with a co-efficient of 0.7329 .

Table 6. Spearman correlation matrix

\begin{tabular}{|c|c|c|c|c|c|c|c|c|c|c|}
\hline & $\begin{array}{l}\text { IMPLE } \\
\text { MENT }\end{array}$ & $\begin{array}{l}\text { QUALI } \\
\text { TY }\end{array}$ & $\begin{array}{l}\text { TOODIF } \\
\text { F }\end{array}$ & $\begin{array}{l}\text { SEEMS } \\
\text { NOTT }\end{array}$ & $\begin{array}{l}\text { LACKO } \\
\text { FHUM }\end{array}$ & $\begin{array}{l}\text { EFFECT } \\
\text { ING }\end{array}$ & $\begin{array}{l}\text { COSTO } \\
\text { FCERT }\end{array}$ & $\begin{array}{l}\text { TOOMU } \\
\mathrm{CP}\end{array}$ & $\begin{array}{l}\text { TIMEIN } \\
\text { VOLV }\end{array}$ & $\begin{array}{l}\text { SOMET } \\
\text { IMESE }\end{array}$ \\
\hline IMPLEMENT & 1.0000 & & & & & & & & & \\
\hline QUALITY & 0.7329 & 1.0000 & & & & & & & & \\
\hline TOODIFF & 0.3588 & 0.3041 & 1.0000 & & & & & & & \\
\hline SEEMSNOTT & 0.2770 & 0.3465 & 0.3809 & 1.0000 & & & & & & \\
\hline LACKOFHUM & 0.5718 & 0.3839 & 0.2905 & 0.4081 & 1.0000 & & & & & \\
\hline EFFECTING & 0.3044 & 0.3924 & 0.2072 & 0.1929 & 0.2259 & 1.0000 & & & & \\
\hline COSTOFCERTH & 0.7726 & 0.5969 & 0.2182 & 0.2930 & 0.4258 & 0.3016 & 1.0000 & & & \\
\hline TOOMUCHP & 0.6379 & 0.4295 & 0.2200 & 0.0851 & 0.3447 & 0.2650 & 0.7116 & 1.0000 & & \\
\hline TIMEINVOLV & 0.4516 & 0.3493 & 0.1099 & -0.0378 & 0.0029 & 0.1440 & 0.5139 & 0.6635 & 1.0000 & \\
\hline SOMETIMESE & 0.4036 & 0.2558 & 0.2734 & 0.1565 & 0.3013 & 0.2821 & 0.3750 & 0.5782 & 0.3454 & 1.0000 \\
\hline
\end{tabular}

IMPLEMENT $=$ implementation cost, QUALITY=quality of consultants, TOODIFF=too difficult to understand, SEEMSNOTT=seems not too beneficial LACKOFHUM=lack of human resources, EFFECTING=affecting the existing organizational structures, COSTOFCERT $=$ cost of certification a bit too high, TOOMUCHP=too much paper work involved in the process, TIMEINVOLV=time involved is a bit too high SOMETIMESET= sometimes exposes the organization to environmental weakness to regulatory bodies to take advantage of.

"Time involve is a bit too high" also correlate with "too much paper work" with a correlation co-efficient of 0.6635 but not severe, "lack of human resources" also correlates with "implementation cost" with a co-efficient of 0.5718 but not severe. "Cost of certification correlates with "implementation cost" with a coefficient of 
0.7726. All other co-efficients were less than 0.60 , which implies that there is no much problem of multicollineary problem among variables used in the study.

\section{Discussions and Conclusions}

In assessing the barriers to the implementation of environmental management system implementation in Ghana, it was clear that, implementation cost and "too much paper work" seems to be the most two important factors that hinders the implementation of environmental management systems in Ghana. This is consistent with Ayirebi-Dansoh, Ayarkwa and Amoah (2010), Goodchild (1998), Bansal and Hunter (2003), Hillary (1998) and Hillary (1997a). This is followed by the cost of certification (see Bansal\& Hunter, 2003), the quality of consultants, the time involved and the exposure of the organizations to regulatory bodies (see Mostek, 1998).

In Ghana, human resource as a barrier to implementation of an environmental management systems does not seems to be a strong force contradicting Poole, Coombs, and Van Gool (1999), Goodchild (1998). This seems to suggest that there seems to be skillful personnel at the organizational level to assist in the implementation of environmental management systems in Ghana.

\section{Implications of the Study}

From the study, respondents made it clear that the key barriers inhibiting environmental management in Ghana are: implementation cost and "too much paper work", cost of certification, the quality of consultants, the time involved and the exposure of the organizations to regulatory bodies. On the issue of cost, it is important for the respective regulatory body and industrial associations to device a way of reducing the cost as well as the paper work involved. In order to reduce the cost of implementation, it would be important for this to bodies to encourage environmental management benchmarking to allow similar sectors to collaborate in developing environmental management systems. In addition to this benchmarking strategy, it would be a important for the regulatory body to encourage environmental management system implementation by involving some of their officers to assist firms planning to implement the system or during the review after implementation.

Another important barrier that was highlighted was the exposure of organizations to regulatory bodies during the planning phase or review. In this case, if regulatory bodies can openly make it clear that besides the regulatory oversight responsibilities to punish offenders polluting knowingly, it is also their responsibility to guide those who are willing to implement systems to reduce pollution. This means whatever, violations observed during planning and implementation would not be used against the respective organizations but will be used as a learning point during the process.

The study also indicates that in Ghana, human resource for the implementation of environmental management system, are somehow available.

This paper contributes to both practice and theory. For practice the results provide insights on the barriers that hinder environmental management implementation in developing country such a Ghana in the quest to achieve sustainable development. Practitioners, including environmental representatives, can use some of the ideas presented in this paper as a guide during the implementation of environmental management systems. For theory, the results can be useful for more comprehensive studies on environmental management system implementation using more data from different countries. Such a study will provide more theoretical understanding of the factors that reduces the implementation of environmental management system in developing and the developed nations.

\section{Limitations and Future Research Directions}

This study considered only ten key factors that hinder the environmental management system implementation in Ghana. Apart from these factors, there is also the need to look at other external and internal factors especially, competition, industrial associations, equipments for environmental monitoring, top management support, training and education" etc that can also affect the implementation of these systems. Future studies can also look at the support of top management as well as the challenges they face in implementing environmental management systems.

\section{References}

Abdul-Rahman, A. A., Sunday, O. A., Idowu, O. O., \& Oyefuga, I. O. (2012). Sustainable Development Policy and Corporate Social Responsibility in Business Organisations in Nigeria. Journal of Sustainable Development, 5(6), 83-89. http://dx.doi.org/10.5539/jsd.v5n6p83

Andrews, R. N. L., Darnall, N., \& Gallagher, D. R. (1999). Environmental Management Systems: A Sustainable Strategy for a Sustainable World? Eighth International Conference of the Greening of Industry Network, Sustainability: Ways of Knowing, Ways of Acting.University of North Carolina.Chapel Hill. 
Anne, T. L., \& Morell, D. (1995). Leading edge environmental management: Motivation, opportunity, resources and processes, Research in corporate social performance and policy. Sustaining the Natural Environment: Empirical Studies on the Interface of Nature and Organizations, Denis Collins and Mark Starik, eds. (Greenwich, CT: JAI Press). 99-126.

Ayarkwa, J. (2010). Perspectives of environmental management in the construction industry in Ghana. International Journal of Sustainable Development, 3, 60-68.

Ayirebi-Dansoh, J. A., \& Amoah, P. (2012). Barriers to implementation of EMS in construction industry in Ghana. International Journal of Engineering Science, 2(4), 37-45.

Bansal, P., \& Hunter, T. (2003). Strategic explanations for the early adoption of ISO 14001. Journal of Business Ethics, 46(3), 289-99. http://dx.doi.org/10.1023/A:1025536731830

Beate, L., \& Erich, G. (2005). Social sustainability: a catchword between political pragmatism and social theory. $\begin{array}{lllll}\text { International Journal of Sustainable Development, } & 8(1 / 2), & 65-79 .\end{array}$ http://dx.doi.org/10.1504/IJSD.2005.007375

Berenz, R. (1997). Die qual der wahl? Qualitaet und Zuverlaessigkeit, 42(3), 285-8.

Butterbrodt, D. (1995). Die oekologische dimension des total quality management. Qualitaet und Zuverlaessigkeit, 40(5), 682-5.

Chandrashekar, A., Dougless, T., \& Avery, G. C. (1999). The environment is free: the quality analogy. Journal of Quality Management, 4(1), 123-43. http://dx.doi.org/10.1016/S1084-8568(99)80099-6

Daily, B. F., \& Huang, S. (2001). Achieving sustainability through attention to human resource factors in environmental management. International Journal of Operations \& Production Management, 21(12), 1539-52. http://dx.doi.org/10.1108/01443570110410892

Darnall, N., Gallagher, D. R., Andrews, R. N. L., \& Amaral, D. (2000). Environmental management systems: opportunities for improved environmental and business strategy. Environmental Quality Management, 9(3), 1-9. http://dx.doi.org/10.1002/1520-6483(200021)9:3<1::AID-TQEM1>3.3.CO;2-C

Erickson, S. L., \& King, B. J. (1999). Fundamentals of Environmental Management. New York, NY: John Wiley $\&$ Sons.

Everett, J., \& Neu, D. (2000). Ecological modernisation and the limits of environmental Accounting. Accounting Forum, 24, 5-29. http://dx.doi.org/10.1111/1467-6303.00027

Figura, S. Z. (1996). Globalizing OH\&S: is ISO the answer? Occupational Hazards, 58(5), 51-3.

Forkert, S., Hofmann von Kap-herr, K., \& Pfeifer, T. (1997). Umweltschutzbetriebsspezifischplanen. Qualitaet und Zuverlaessigkeit, 42(7), 770-4.

GohEng Ann, SuhaizaZailani, \& NabsiahAbd, W. (2006). A study on the impact of environmental management system (EMS) certification towards firms' performance in Malaysia. Management of Environmental Quality: An International Journal, 17(1), 73-93. http://dx.doi.org/10.1108/14777830610639459

Goodchild, E. (1998). The Business Benefits of EMS Approaches, PhD, Salford University, Salford.

Gray, R. (2010). Is accounting for sustainability actually accounting for sustainability and how would we know? An exploration of narratives of organisations and the planet. Accounting, Organizations and Society, 35(1), 47-62. http://dx.doi.org/10.1016/j.aos.2009.04.006

GyulaVastag. (2003). Revisiting ISO 14000 Diffusion: A New "Look" at the Drivers of Certification. Kelley School of Business. Indiana University.

Hale, G. (1997). ISO 14000 integration tips. Received August 28, 2011, from www.qualitydigest.com/feb97/ISO14000.html

Hanna, M. D. W., Newman, R., \& Johnson, P. (2000). Linking operational and environmental improvement through employee involvement. International Journal of Operations \& Production Management, 20(2), 148-65. http://dx.doi.org/10.1108/01443570010304233

Hawken, P. (1993). The Ecology of Commerce. New York, NY: Harper Business. PMCid: PMC1015374

Helling, K., \& Herrmann, J. (1997). Aenderungen flexible meistern. Qualitaet und Zuverlaessigkeit, 42(6), 670-5.

Hillary, R. (1997a). The Eco-management and Audit Scheme: Analysis of the Regulation, Implementation and Support. Imperial College, University of London. 
Hillary, R. (1998). An Assessment of the Implementation Status of Council Regulation (No 1836/93) Eco-management and Audit Scheme (EMAS) in the European Union Member States (AIMS-EMAS). London, UK: Imperial College.

KPMG Environmental Consulting. (1997). The Environmental Challenge and Small and Medium-sized Enterprises in Europe. The Hague.

Krut, R., \& Gleckman, H. (1998). ISO 14001: A Missed Opportunity for Sustainable Global Industrial Development. Earthscan Publications, London.

Lee-Mortimer, A. L. (2000). Waste not, want not. Works Management, 53(5), 42-4.

Lutz, J. A. (2000). Management systems update: the future of ISO 14000. ASQ's 5th Annual Conference Proceedings, ASQ, Milwaukee, WI, pp. 4485-7.

Maxwell, J., Rothenberg, S., Briscoe, F., \& Marcus, A. (1997). Green schemes: corporate environmental strategies and their implementation. California Management Review, 39(3), 118-20. http://dx.doi.org/10.2307/41165902

Melnyk, S. A., Sroufe, R. P., \& Calantone, R. (2003). Assessing the impact of environmental management systems on corporate and environmental performance. Journal of Operations Management, 21(3), 329-51. http://dx.doi.org/10.1016/S0272-6963(02)00109-2

Mostek, S. M. (1998). Limited Privilege and Immunity for Self-Evaluative Environmental Audits in Nebraska. Moving Environmental Performance to the Next Level, 32 CREIGHTON L. REV. 545.

Naomi Roht-Arriaza. (1995). Shifting the Point of Regulation: The International Organization for Standardization and Global Lawmaking on Trade and the Environment. 22 ECOLOGY L.Q. 479, 522-38.

National Association of Local Authorities in Denmark (NALAD). (1997). Guide for the Promotion of Cleaner Technology and Responsible Entrepreneurship. NALAD, Copenhagen.

Nee, G. Y., \& Nabsiah, A. W. (2010). The Effect of ISO 14001 Environmental Management System Implementation on SMEs Performance: An Empirical Study in Malaysia. Journal of Sustainable Development, 3(2), 215.

Poole, M., Coombs, J., \& Van Gool, K. (1999). The Environmental Needs of the Micro company Sector and the Development of a tool to meet those Needs. Payback Business Environmental Association for the Southwest, Plymouth.

Porter, M., \& van der Linde, C. (1995). Green and competitive: ending the stalemate. Harvard Business Review, 121-34.

Rahaman, A. S., Lawrence, S., \& Roper, J. (2004). Social and environmental reporting at the VRA: institutionalised legitimacy or legitimation crisis? Critical Perspectives on Accounting, 15(1), 35-56. http://dx.doi.org/10.1016/S1045-2354(03)00005-4

Ritchie, I., \& Hayes, W. (1998). A Guide to the Implementation of ISO 14000 Series on Environmental Management. Prentice Hall, NJ.

Sameer, K., \& Julie, F. (2005). Analysis of European Union environmental directives and producer responsibility requirements. International Journal of Services and Standards, 1(3), 379-398. http://dx.doi.org/10.1504/IJSS.2005.005806

Schaarsmith, J. H. (2000). ISO 14001 lowers environmental risks. Business Insurance, 3(28), 12.

Sissell, K. (1996). One size fits all: unifying ISO management. Chemical Week, 158(13), 27-36.

Standards Australia. (1996). Environmental Management Systems: Specification with Guidance for Use. Australian/New Zealand Standard 14001: 1996, Standards Australia, Sydney.

Stielow, J. (1997). Gemeinsamgehtesleichter. Qualitaet und Zuverlaessigkeit, 42(7), 786-8.

Whitelaw, K. (1997). ISO 14001 Environmental Systems Handbook. Butterworth-Heinemann, Oxford. PMCid:PMC231886

Williamson, O. E. (1996). The Mechanisms of Governance. New York, Oxford: Oxford University Press.

Zingale, R., \& Himes, T. (1999). Environmental management systems: making better business sense. Industrial Heating, 66(8), 18, 34. 


\section{Copyrights}

Copyright for this article is retained by the author(s), with first publication rights granted to the journal.

This is an open-access article distributed under the terms and conditions of the Creative Commons Attribution license (http://creativecommons.org/licenses/by/3.0/). 